\title{
Financial reporting of intangible assets - evidence on information and communication companies in Czech Republic
}

\author{
Olga Malíková \\ Faculty of Economics, Technical University of Liberec \\ Czech Republic \\ olga.malikova@tul.cr. \\ Zdeněk Brabec \\ Faculty of Economics, Technical University of Liberec \\ Czech Republic \\ zdenek.brabec@tul.cr. \\ Jiř́ Rozkovec \\ Faculty of Economics, Technical University of Liberec \\ Czech Republic \\ jirirozkoved@tul.cr
}

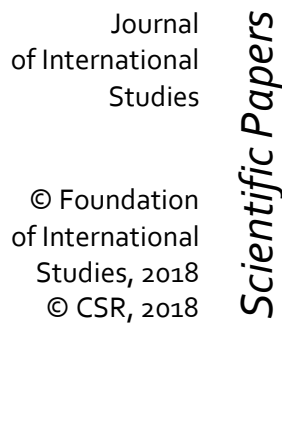

Abstract. Intangible assets are becoming an increasingly important part of companies' assets. However, their recognition and measurement in financial statements is often complicated and is subject to the requirements of a given accounting regulation. Therefore, the objective of this article is to find out the relationship between the size of a company and the disclosure of intangible assets. To do so, financial statements of companies operating in the field of information and communications published between the years 2005 and 2015 are anal.ysed. The established hypotheses are tested using the methods of descriptive statistics, the Chi-Square test of independence and the method of Spearman rank correlation. The results of this research confirm that larger companies publish their financial statements for a longer period than smaller ones. Subsequently, it was found that the structure of publishing companies, as well as companies disclosing intangible assets does not change over time. In addition, it has been concluded that larger companies disclose intangible assets more often than smaller ones. Finally, it was confirmed that the share of intangible assets to fixed assets is higher in larger companies. 
Keywords: Czech Republic, financial reporting, chi-square test of independence, information and communication technologies, intangible assets, Spearman rank correlation.

JEL Classification: M15, M41, M48

\section{INTRODUCTION}

Most advanced economies in the world are gradually moving towards the knowledge economy. At present, industry is at the forefront of the so-called Industry 4.0 concept that is based primarily on automation, robotics and digitization of the economy. A necessary prerequisite for successful operation of this concept is knowledge (Sedlacek, 2014). According to (Clausen, 2016), changes in market capitalization are positively related to $R \& D$ expenditures. Many companies spend huge amounts of capital on intangible investment, which is mainly developed within a company. This shift highlights the necessity and the importance of measuring the contribution of intangible assets to overall welfare (Nakamura, 2008).

Intangible assets are becoming an increasingly important part of company's assets. Nakamura (2010) points out that expenditures on intangible assets have risen from roughly 4\% of US GDP in 1977 to 9-10\% in 2006. The proportion of intangibles to total fixed assets as reported by the US companies increased from around 5\% in 1978 to 75-85\% at present (Svoboda, 2017). In addition to this, Hall \& Kim (2000) estimate the total value of intangible capital as ranging between half to two-thirds of the total market value of publicly traded corporations, as indicated by the $q$ ratio (market value to replacement cost of physical assets). In addition, intangible assets contribute to economic growth in a considerable way. Corrado et al. (2009), for example, claim that only $8 \%$ of economic growth can be attributed to traditional basic capital investments. According to the research conducted in ten European Union countries, Niebel, O’Mahony and Saam (2017) also confirmed the contribution of intangibles to productivity growth based on growth accounting and econometric estimation of production function.

In the Czech context, (Sabolovic, 2011) captured the growing trend of the share of intangible assets in the total return value of enterprises. However, many intangible assets, such as the value of research and development, patents, educated workforce, the quality of company management, the stability of suppliercustomer relationships cannot be captured in financial statements, although they have a significant effect on market value of enterprises (Jac, 2015). It can also be stated that the share of intangibles as compared to fixed tangible assets reported by listed companies at the Prague Stock Exchange is very small (Brabec, 2016).

The aim of this article, taking into account that the issue of intangible assets' reporting is solved only partially in Czech Republic, is to contribute to the discussion on this topic by providing new research results, which are focused on financial reporting of intangible assets by enterprises operating in the field of information and communications in Czech Republic. Moreover, stemming from the previous research performed by (Hasprova et al., 2016) the authors try to find out the relationship between the size of a company and the disclosure of intangible assets using appropriate statistical methods. The question is whether the length of the publishing period and the ratio between intangible and tangible assets does change with a company growing in size. In addition to that, the relationship between the publication of intangible assets and company's size will be studied. 


\section{LITERATURE REVIEW}

\subsection{Recognition of intangibles}

The issue of recognition (as well as measuring) of intangible assets is a topic that has been debated by specialists on accounting since at least the 1950s and has been elaborated to some extent in articles by worldrenowned authors and partly in publications by local authors, too. For example, Lev (2003) proposes a socalled "comprehensive balance sheet" to provide investors with information on the financial situation of the company before and after including the capitalization of intangible assets. Another contribution to this discussion is "Invisible Balance Sheet" developed by Sveiby (1989). The inclusion of unrecognized items of intangible assets in the financial statements is also proposed by Wyatt (2003). Michalczuk and Widelska (2016) state that the scope of reporting in the area of intangible assets is determined, on the one hand, by the constraints of the effective accounting standards and, on the other hand, by the information policy of companies in the area of disclosures regarding to those intangible assets which do not meet the definition of assets and are not expressed as items in the balance sheet.

Capturing knowledge in accounting is, however, very difficult and sometimes unrealizable due to the requirements of accounting regulators. The actual value of an intangible asset can only be ascertained if the enterprise participates in a particular acquisition or merger (Sedlacek, 2014). Recognition of assets that are created inside a business and are not for sale is very complicated because it is not possible to directly determine their economic benefits. Incorrect disclosure of intangible assets usually causes a systematic under-valuation of large volumes of intangible assets (Sedlacek, 2010).

According to the research done by Krstic and Dordevic (2010), many European businesses voluntarily report on intangible assets or intellectual capital, which will greatly reduce the gap between the company's accounting and market value. These techniques should eliminate the information asymmetry between business management and external users of accounting information. If this information is not publicly available, the value of the company is usually determined on the basis of estimates by financial analysts. These estimates, however, depend on their ability to assess the future benefits of using intangible assets. (Gu, 2005) Schiemann et al. (2015) found that the magnitude of recognized intangible assets is significantly and negatively associated with the quantity and quality of voluntarily disclosed intellectual capital. In a more detailed analysis the authors found different directions (positive, negative and insignificant) of this relationship for different categories of intellectual capital.

The amount of intangible assets disclosed in financial statements may be also used for evaluating the performance of entities operating in the public sector. According to Hasprová et al. (2018) the value of intangible assets may be, under certain conditions, used to measure the performance of Czech public universities.

\subsection{Accounting regulation on intangibles in the Czech Republic}

Monitoring and analyzing intangible assets held by business entities has become the world's standard approach in recent years. Individual approaches can be found in studies performed by Lev, (2004), Salojärvi et al. (2005) or Helmers (2009). When determining the value of intangible assets used in companies, the accounting value of intangible assets is used in most cases. Therefore, it is necessary to consider the influence of a given accounting system according to which the financial statements are prepared. The requirements of individual accounting systems usually differ in the areas of recognition and measurement of intangible assets or by determination of their direct or indirect influence on the performance and value of a company (Stolowy \& Jeny-Cazavan, 2001). 
Regulation of financial reporting can be monitored at different levels. In continental Europe, at the national level, accounting is mostly regulated by the government through the legislative process. Multinational companies, and in particular those having publicly traded securities on any public financial market within the European Union, must publish their financial statements in accordance with International Financial Reporting Standards IFRS (Nobes, 2016).

International Financial Reporting Standards (IFRS) allow for intangible assets to be reported only if they comply with the general definition of assets set out in the Conceptual Framework and the very detailed rules for recognition and reporting of intangible assets set out in international standards, namely in IAS 38, which focuses on intangibles (IASB, 2018).

On the contrary, the legislation regulating the reporting of intangible assets in the Czech Republic does not provide any general definition of intangible assets. It only sets an explicit list of items that can be recognized as intangible assets, as well as items that cannot be recognized as intangible assets. Moreover, Czech accounting legislation contains only a very vague description of the conditions under which intangible assets can be recorded, written off and reported (Hasprova, 2014; Krizova, 2016).

Furthermore, reporting of intangible assets in the Czech Republic is governed by the relevant provisions of the six different implementing decrees to the Act on Accounting, focusing on different types of entities. For this purpose, accounting entities are classified into entrepreneurs, financial institutions, commercial insurance and reinsurance institutions, health insurance institutions, non-profit organizations and governmental organizations. In addition to this, it is possible to trace individual declarations of the difference in which intangible items can be recognized for reporting in these decrees. (Act on Accounting)

According to research focusing on information and communication companies, it is necessary to briefly describe how intangible assets are defined by Czech legislation for business entities. Decree No. 500/2002 Coll., on Accounting Act, for entrepreneurs, sets that intangible assets include, inter alia, intangible results of research, software and valuation rights and goodwill with a useful life longer than one year and the valuation determined by the entity. Recognition of these items is allowed once the conditions set forth the obligations laid down by the Act on Accounting are respected. This means, in particular, respecting the principle of materiality and fair and true representation of the company's resources. It also contains emission allowances and preferential limits. Economic lifetime of intangible refers to the length of time that the asset can be used for current or future business activity, or may serve as the basis or component of the improved or other processes and solutions, including the time to verify the intangible results (Decree No. 500/2002 Coll.)

Under Czech accounting law, intangibles are recognized only as long-lived assets. They also include the technical appreciation of intangibles, which value limit corresponds to regulation by the Act on Income Taxes. The charging and amortization policy is set by the accounting entity itself. Intangible assets that do not meet the conditions for recognition and reporting are expensed. (Decree No. 500/2002 Coll.)

Intangible results of development and software are recognized only if they are either created internally for the purpose of trading with them or are acquired from other entities. This is also applied for other valuable rights, which include, in particular, the objects of industrial and similar ownership and represent the results of intellectual creative activity and rights under special legal regulations (such licenses, trademarks, technical know-how, patents etc.). Goodwill for the purposes of this Decree, in the context of the transformation of a business corporation, is set as positive or negative difference between the fair / market value associated with a transaction with corporations and the sum of its individually revalued items of assets after deduction of any unpaid liability. Positive as well as negative amount of goodwill is amortized within 60 months using a straight-line method. If it is created during the transformation of a company, it is amortized from the effective date of this transformation. Any potential change in the purchase price of the business will adjust the value of goodwill or negative goodwill, without changing the depreciation period.

According to Czech accounting legislation, entrepreneurs are obliged to recognize and report emission allowances and preferential limits as long-lived assets, even if their life-time does not exceed one year. 
Acquisition cost is not limited. The Czech Ministry of Finance regulates the emission allowances in the case of greenhouse gas emission allowances and allowances for aviation emissions and reduction units and verified emissions reductions from project activities. Preferential limits are regulated, in particular, by using individual production quotas and individual premium rights only if the cost of obtaining information on their valuation at reproductive cost has not exceeded its materiality. (Decree No. 500/2002 Coll.)

Physical objects arising from the acquisition of intangible assets, in particular, prototypes, models, other physical items, unless they are discarded, for example, due to sale or disposal, shall be accounted for in the relevant tangible asset for further use in their own activities. In the case of a variant of the procedure for the acquisition of a long-term intangible asset or any part thereof, all options are included in the valuation of intangible assets.

Companies are also required to report separately intangible assets under the process of their acquisition. These include the acquired intangible fixed assets during the period of their acquisition until they become available for use and also any short-term and long-term advanced payments and deferrals granted for the acquisition of intangibles.

Czech accounting legislation also explicitly states that as intangible assets are not recognized, in particular, expert opinions, market surveys, development plans, promotional proposals, quality system certifications and technology management software or equipment that cannot function without this software. In addition, an entity may decide that, as intangibles are not primarily recognized technical audits and energy audits, forest management plans and river basin plans. (Decree No. 500/2002 Coll.)

As mentioned above, there is a significant difference in the approaches to recognition, valuation and reporting of intangible assets embodied in the Czech accounting legislation and IFRS. IFRS focus more on concepts, while the Czech accounting legislation is working with the list of items. IFRS reporting for Czech companies is only obliged if they are listed on public markets in an EU Member State or they are part of a consolidated group of companies. In other cases, companies report according to the Czech legislation. For example, the research conducted by Cheung and Lau (2016) has shown that financial reports are significantly lengthier, yet are more readable in the post-IFRS period (after adopting IFRS reporting in the company). Further, the length of disclosures in Summary of Significant Accounting Policies, Financial Instruments and Intangible Assets are significantly longer after the adoption of IFRS. So we propose unifying the accounting regulation and continuing in the process of accounting harmonization to European rules.

\section{METHODOLOGY}

\subsection{Description of the surveyed set of enterprises}

Krizova (2017) states that recent growth of the service sector and of the information technology-related business, along with the dramatic increase in the number and size of mergers and acquisitions, has made accounting for intangible assets very significant.

The selection of a research sample used to study the issue whether and to what extent companies disclose information on intangible assets is based on the assumption that companies operating in the field of information and communication activities are significant producers of intangible assets.

For this purpose, the companies belonging to the category "J - Information and Communication Activities" are selected according to the Czech Statistical Classification of Economic Activities CZ-NACE. These companies deal with the production and distribution of information and communication products, the provision of means for their distribution and for the mediation of data or communication, information technology activities, data processing, publishing (publishing of books, periodical publications, computer games software, audio books etc.). They are also active in the field of films, television programs and music publishing activities, programming and broadcasting both radio and television. As part of the 
telecommunication activity, they are companies that are involved in fixed, wireless and satellite networks. In the field of information technology, it concerns activities such as programming and management of computer equipment. Last but not least, information activities related to data processing, hosting, web portals, etc. are included.

The research sample includes Czech companies with activities named above, which are joint-stock companies from a legal point of view and they report according Czech accounting legislation. As the source of the data, the Bisnode Magnus web database is used. To establish the research sample, only companies that were active in the year 2015 and were classified in the category "J" according to the CZ-NACE are selected. Based on this assumption the research sample contains 818 companies. The year 2015 is selected deliberately, because more recent data are not available. That is because the vast majority of companies included in the research sample failed to comply with legal requirements and did not publish the financial statements for the year 2016 until the end of 2017.

Although companies are obliged to publish their financial statements in a public register, some companies do not respect this requirement. Reflecting that, only 667 companies have published their financial statements at least once. The others did not, probably because there is no sanction if they fail to comply with the legislative requirements.

Table 1

The size structure of the research sample

\begin{tabular}{|l|c|c|}
\hline \multirow{2}{*}{ Category } & \multicolumn{2}{|c|}{ Number or companies } \\
\cline { 2 - 3 } & Absolute & Relative \\
\hline Micro & 342 & 0.5128 \\
\hline Small & 225 & 0.3373 \\
\hline Medium-sized & 80 & 0.1199 \\
\hline Large & 20 & 0.0300 \\
\hline Total & 667 & 1.0000 \\
\hline
\end{tabular}

Source: Own elaboration

Table 2

The criteria used for classifying companies

\begin{tabular}{|c|c|c|c|c|}
\hline \multirow{2}{*}{ Criterion } & \multicolumn{4}{|c|}{ Category } \\
\hline & Micro & Small & Medium-sized & Large \\
\hline \multirow{2}{*}{$\begin{array}{l}\text { Total net assets in } \\
\text { CZK }\end{array}$} & \multirow{2}{*}{$\leq 9,000,000$} & $>9,000,000$ & $>100,000,000$ & \multirow{2}{*}{$>500,000,000$} \\
\hline & & $\leq 100,000,000$ & $\leq 500,000,000$ & \\
\hline \multirow{2}{*}{$\begin{array}{l}\text { Net annual } \\
\text { turnover in CZK }\end{array}$} & \multirow{2}{*}{$\leq 18,000,000$} & $>18,000,000$ & $>200,000,000$ & \multirow{2}{*}{$>1,000,000,000$} \\
\hline & & $\leq 200,000,000$ & $\leq 1,000,000,000$ & \\
\hline \multirow{2}{*}{$\begin{array}{l}\text { Average number of } \\
\text { employees }\end{array}$} & \multirow{2}{*}{$\leq 10$} & $>10$ & $>50$ & \multirow{2}{*}{$>250$} \\
\hline & & $\leq 50$ & $\leq 250$ & \\
\hline
\end{tabular}

Source: Own elaboration according to the Act No. 563/1991 Coll., on Accounting

The research sample is classified according to the size of the analyzed companies (see Table 1). As a sorting feature, the requirements of the Act No. 563/1991 Coll., on Accounting are used (see Table 2).

\subsection{Description of used research methods}

The aim of the article is to test the above mentioned statements related to the disclosure of intangible assets with the reality in the Czech Republic. For that purpose, the following hypotheses are set: 
H1 The length of time for which companies publish their financial statements is not dependent on their size

H2 The structure of publishing companies does not change over time

H3 The structure of companies disclosing intangible assets does not change over time

H4 The ratio between intangible and tangible assets does not change with the rising amount of net total assets

Firstly, the issue of publishing financial statements by selected Czech companies is tested. The ChiSquare test of independence is used to analyze both the length of publishing period and the structure of publishing companies.

Subsequently, the amount of intangible assets disclosed by the analyzed companies is studied. For this purpose, the methods of descriptive statistics are used. Furthermore, the relationship between the ratio which measures the proportion of intangible assets to tangible ones and net total assets is studied. To test this relationship, the correlation analysis is used.

The net value of assets is measured at historical cost. Authors, intentionally, do not convert the values at historical cost to real prices using the consumer price index published by the Czech statistical office. According to the authors, the asset structure disclosed by business entities differs significantly from the items included into the consumer basket used for the calculation of the consumer price index. Conversion would, therefore, replace one price distortion by another.

\section{EMPIRICAL RESULTS AND DISCUSSION}

\subsection{Publication of financial statements by companies}

Based on the data available in the Bisnode database the number of companies publishing their financial statements is studied. From the total of 818 companies embodied in the research sample, 667 published at least one financial statement. As shown in table 3 the share of publishing companies is ranging from 59.85\% to $74.79 \%$ during the analyzed period. The share is, at first, rising and then, at the end of the period the number is decreasing. This may be due to the incapability of the companies publishing their financial statements in time. If the analysis was repeated later the number of companies publishing financial statements in the last two years would probably rise.

Table 3

The share of publishing companies in the research sample

\begin{tabular}{|l|c|c|c|}
\hline Year & $\begin{array}{c}\text { Number of publishing } \\
\text { companies }\end{array}$ & $\begin{array}{c}\text { Number of existing } \\
\text { companies }\end{array}$ & $\begin{array}{c}\text { Share in \% } \\
\text { (reporting/existing) }\end{array}$ \\
\hline 2005 & 310 & 518 & 59.85 \\
\hline 2006 & 353 & 541 & 65.25 \\
\hline 2007 & 395 & 604 & 65.40 \\
\hline 2008 & 438 & 636 & 68.87 \\
\hline 2009 & 486 & 671 & 72.43 \\
\hline 2010 & 515 & 707 & 72.84 \\
\hline 2011 & 528 & 706 & 74.79 \\
\hline 2012 & 522 & 742 & 70.35 \\
\hline 2013 & 517 & 757 & 68.30 \\
\hline 2014 & 494 & 782 & 63.17 \\
\hline 2015 & 460 & 818 & 56.23 \\
\hline
\end{tabular}

Source: Own elaboration 
Subsequently, the structure of publishing companies is analyzed. At first, the length of the publishing period is studied. Table 4 contains the absolute and relative frequency for the four groups classifying companies according to their size. The rows include the length of the publishing period ranging from one period to the entire analyzed period with 11 years. Based on the results of the independent Chi-Square test, it can be concluded that larger companies publish their financial statements over a longer period than smaller ones. As the P-Value of the Chi-Square test is lower than 0.05 (see table 5), the H1 hypothesis may be rejected at the $95.0 \%$ confidence level. The share of micro companies is falling with the increasing length of the publishing period. On the other hand, the share of small, medium-sized and large companies is rising.

Table 4

The length of publishing period according to the size structure

\begin{tabular}{|c|c|c|c|c|c|c|c|c|c|c|}
\hline \multirow{3}{*}{$\begin{array}{l}\text { Number } \\
\text { of } \\
\text { years }\end{array}$} & \multicolumn{10}{|c|}{ Number of disclosing companies } \\
\hline & \multicolumn{2}{|c|}{ Micro } & \multicolumn{2}{|c|}{ Small } & \multicolumn{2}{|c|}{ Medium-sized } & \multicolumn{2}{|c|}{ Large } & \multicolumn{2}{|c|}{ Total } \\
\hline & $\mathrm{n}_{\mathrm{i}}$ & $\mathrm{p}_{\mathrm{i}}$ & $\mathrm{n}_{\mathrm{i}}$ & $\mathrm{p}_{\mathrm{i}}$ & $\mathbf{n}_{\mathrm{i}}$ & $p_{i}$ & $\mathbf{n}_{\mathrm{i}}$ & $\mathrm{p}_{\mathrm{i}}$ & $\mathbf{n}_{\mathrm{i}}$ & $\mathrm{p}_{\mathrm{i}}$ \\
\hline 1 & 24 & $72.73 \%$ & 8 & $24.24 \%$ & 0 & $0.00 \%$ & 1 & $3.03 \%$ & 33 & $4.95 \%$ \\
\hline 2 & 34 & $85.00 \%$ & 5 & $12.50 \%$ & 0 & $0.00 \%$ & 1 & $2.50 \%$ & 40 & $6.00 \%$ \\
\hline 3 & 21 & $60.00 \%$ & 8 & $22.86 \%$ & 5 & $14.29 \%$ & 1 & $2.86 \%$ & 35 & $5.25 \%$ \\
\hline 4 & 31 & $70.45 \%$ & 13 & $29.55 \%$ & 0 & $0.00 \%$ & 0 & $0.00 \%$ & 44 & $6.60 \%$ \\
\hline 5 & 30 & $71.43 \%$ & 11 & $26.19 \%$ & 1 & $2.38 \%$ & 0 & $0.00 \%$ & 42 & $6.30 \%$ \\
\hline 6 & 30 & $53.57 \%$ & 18 & $32.14 \%$ & 7 & $12.50 \%$ & 1 & $1.79 \%$ & 56 & $8.40 \%$ \\
\hline 7 & 22 & $61.11 \%$ & 11 & $30.56 \%$ & 3 & $8.33 \%$ & 0 & $0.00 \%$ & 36 & $5.40 \%$ \\
\hline 8 & 39 & $67.24 \%$ & 13 & $22.41 \%$ & 5 & $8.62 \%$ & 1 & $1.72 \%$ & 58 & $8.70 \%$ \\
\hline 9 & 31 & $53.45 \%$ & 21 & $36.21 \%$ & 5 & $8.62 \%$ & 1 & $1.72 \%$ & 58 & $8.70 \%$ \\
\hline 10 & 35 & $46.67 \%$ & 30 & $40.00 \%$ & 9 & $12.00 \%$ & 1 & $1.33 \%$ & 75 & $11.24 \%$ \\
\hline 11 & 45 & $23.68 \%$ & 87 & $45.79 \%$ & 45 & $23.68 \%$ & 13 & $6.84 \%$ & 190 & $28.49 \%$ \\
\hline Total & 342 & $51.27 \%$ & 225 & $33.73 \%$ & 80 & $11.99 \%$ & 20 & $3.00 \%$ & 667 & $100.00 \%$ \\
\hline
\end{tabular}

Source: Own elaboration

Table 5

Test of independence

\begin{tabular}{|l|c|c|c|}
\hline Test & Statistic & Degrees of freedom & P-Value \\
\hline Chi-Square & 126.178 & 30 & 0.0000 \\
\hline
\end{tabular}

Source: Own elaboration

Subsequently, the structure of publishing companies in individual years is analyzed. Table 6 contains absolute and relative frequency for the four groups classifying companies according to their size. Based on the results of the independent Chi-Square test, it can be concluded that the structure of publishing companies does not change over time. As the P-Value of the Chi-Square test is higher than 0.05 (see table 7), the H2 hypothesis cannot be rejected at the $95.0 \%$ confidence level. 
Table 6

The structure of publishing companies in individual years

\begin{tabular}{|l|c|c|c|c|c|c|c|c|c|c|}
\hline \multirow{2}{*}{$\begin{array}{l}\text { Number } \\
\text { of } \\
\text { years }\end{array}$} & \multicolumn{9}{|c|}{ Number of disclosing companies } \\
\cline { 2 - 12 } & \multicolumn{2}{|c|}{ Micro } & \multicolumn{2}{|c|}{ Small } & \multicolumn{1}{c|}{ Medium-sized } & \multicolumn{2}{|c|}{ Large } & \multicolumn{2}{c|}{ Total } \\
\cline { 2 - 12 }$y$ & $\mathbf{n}_{\mathbf{i}}$ & $\mathbf{p}_{\mathbf{i}}$ & $\mathbf{n}_{\mathbf{i}}$ & $\mathbf{p}_{\mathbf{i}}$ & $\mathbf{n}_{\mathbf{i}}$ & $\mathbf{p}_{\mathbf{i}}$ & $\mathbf{n}_{\mathbf{i}}$ & $\mathbf{p}_{\mathbf{i}}$ & $\mathbf{n}_{\mathbf{i}}$ & $\mathbf{p}_{\mathbf{i}}$ \\
\hline 2005 & 123 & $39.68 \%$ & 116 & $37.42 \%$ & 55 & $17.74 \%$ & 16 & $5.16 \%$ & 310 & $6.18 \%$ \\
\hline 2006 & 146 & $41.36 \%$ & 133 & $37.68 \%$ & 58 & $16.43 \%$ & 16 & $4.53 \%$ & 353 & $7.03 \%$ \\
\hline 2007 & 158 & $40.00 \%$ & 157 & $39.75 \%$ & 64 & $16.20 \%$ & 16 & $4.05 \%$ & 395 & $7.87 \%$ \\
\hline 2008 & 185 & $42.24 \%$ & 170 & $38.81 \%$ & 67 & $15.30 \%$ & 16 & $3.65 \%$ & 438 & $8.73 \%$ \\
\hline 2009 & 227 & $46.71 \%$ & 176 & $36.21 \%$ & 67 & $13.79 \%$ & 16 & $3.29 \%$ & 486 & $9.69 \%$ \\
\hline 2010 & 238 & $46.21 \%$ & 187 & $36.31 \%$ & 73 & $14.17 \%$ & 17 & $3.30 \%$ & 515 & $10.26 \%$ \\
\hline 2011 & 243 & $46.02 \%$ & 195 & $36.93 \%$ & 73 & $13.83 \%$ & 17 & $3.22 \%$ & 528 & $10.52 \%$ \\
\hline 2012 & 235 & $45.02 \%$ & 195 & $37.36 \%$ & 75 & $14.37 \%$ & 17 & $3.26 \%$ & 522 & $10.40 \%$ \\
\hline 2013 & 235 & $45.45 \%$ & 190 & $36.75 \%$ & 74 & $14.31 \%$ & 18 & $3.48 \%$ & 517 & $10.30 \%$ \\
\hline 2014 & 215 & $43.52 \%$ & 187 & $37.85 \%$ & 75 & $15.18 \%$ & 17 & $3.44 \%$ & 494 & $9.84 \%$ \\
\hline 2015 & 194 & $42.17 \%$ & 178 & $38.70 \%$ & 72 & $15.65 \%$ & 16 & $3.48 \%$ & 460 & $9.17 \%$ \\
\hline Total & 2199 & $43.62 \%$ & 1884 & $37.54 \%$ & 753 & $15.01 \%$ & 182 & $3.63 \%$ & 5018 & $100.00 \%$ \\
\hline
\end{tabular}

Source: Own elaboration

Table 7

Test of independence

\begin{tabular}{|l|c|c|c|}
\hline Test & Statistic & Degrees of freedom & P-Value \\
\hline Chi-Square & 15.621 & 30 & 0.9857 \\
\hline
\end{tabular}

Source: Own elaboration

Based on the results of this analysis, it can be stated that, on average, publishing companies include 43.62\% micro companies, 37.54\% small companies, $15.01 \%$ medium-sized companies and 3.63\% large companies.

\subsection{Intangible assets disclosed by selected companies}

Firstly, the amount of intangible assets disclosed by analyzed companies in is studied. Table 8 shows summary statistics for the groups classifying companies according to their size. Number of financial statements analyzed (count) is expressed in numbers, the others statistics are expressed in CZK.

In the next step, the structure of companies disclosing intangible assets is studied. The companies that published their financial statements (see Table 6) are used as a basis for this subsequent analysis. Table 9 contains the absolute and relative frequency for the four groups classifying companies disclosing intangible assets according to their size covering individual years in the research period. Based on the results of the independent test, it can be concluded that the structure of companies disclosing intangible assets does not change over time. As the P-Value of the Chi-Square test is higher than 0.05 (see table 10), the H3 hypothesis cannot be rejected at the $95.0 \%$ confidence level. Based on the results of this analysis, it can be stated that, on average, companies disclosing their financial assets include 25.93\% micro companies, 43.40\% small companies, $24.30 \%$ medium-sized companies and $6.37 \%$ large companies. 
Table 8

Summary statistics describing the intangible assets disclosed by the analyzed companies

\begin{tabular}{|c|c|c|c|c|c|}
\hline \multirow[b]{2}{*}{ Statistic } & \multicolumn{4}{|c|}{ Category } & \multirow[b]{2}{*}{ Total } \\
\hline & Micro & Small & $\begin{array}{l}\text { Medium- } \\
\text { sized }\end{array}$ & Large & \\
\hline Count & 1,974 & 1,787 & 745 & 181 & 4,687 \\
\hline Average & $1,263,800$ & $3,917,670$ & $9,055,830$ & $841,968,000$ & $35,979,500$ \\
\hline Median & 0 & 197,000 & $2,474,000$ & $53,924,000$ & 85,000 \\
\hline Standard deviation & $7,457,590$ & $13,225,800$ & $16,251,900$ & $1,865,380,000$ & $399,874,000$ \\
\hline Minimum & 0 & $-48,000$ & $-90,009,000$ & 0 & $-90,009,000$ \\
\hline Maximum & $134,920,000$ & $147,880,000$ & $138,087,000$ & $8,266,000,000$ & $8,266,000,000$ \\
\hline Lower Quartile & 0 & 0 & 437,000 & $3,634,000$ & 0 \\
\hline Upper Quartile & 116,000 & $2,267,000$ & $11,663,000$ & $174,335,000$ & $2,145,000$ \\
\hline
\end{tabular}

Source: Own elaboration

Table 9

The structure of companies disclosing intangible assets in individual years

\begin{tabular}{|l|c|c|c|c|c|c|c|c|c|c|}
\hline \multirow{2}{*}{$\begin{array}{l}\text { Number } \\
\text { of } \\
\text { years }\end{array}$} & \multicolumn{9}{|c|}{ Number of disclosing companies } \\
\cline { 2 - 12 } & \multicolumn{2}{|c|}{ Micro } & \multicolumn{2}{|c|}{ Small } & \multicolumn{2}{c|}{ Medium-sized } & \multicolumn{2}{|c|}{ Large } & \multicolumn{2}{c|}{ Total } \\
\cline { 2 - 12 } & $\mathbf{n}_{\mathbf{i}}$ & $\mathbf{p}_{\mathbf{i}}$ & $\mathbf{n}_{\mathbf{i}}$ & $\mathbf{p}_{\mathbf{i}}$ & $\mathbf{n}_{\mathbf{i}}$ & $\mathbf{p}_{\mathbf{i}}$ & $\mathbf{n}_{\mathbf{i}}$ & $\mathbf{p}_{\mathbf{i}}$ & $\mathbf{n}_{\mathbf{i}}$ & $\mathbf{p}_{\mathbf{i}}$ \\
\hline 2005 & 50 & $27.03 \%$ & 75 & $40.54 \%$ & 45 & $24.32 \%$ & 15 & $8.11 \%$ & 185 & $6.69 \%$ \\
\hline 2006 & 61 & $29.05 \%$ & 82 & $39.05 \%$ & 52 & $24.76 \%$ & 15 & $7.14 \%$ & 210 & $7.59 \%$ \\
\hline 2007 & 57 & $24.89 \%$ & 98 & $42.79 \%$ & 58 & $25.33 \%$ & 16 & $6.99 \%$ & 229 & $8.28 \%$ \\
\hline 2008 & 69 & $27.38 \%$ & 109 & $43.25 \%$ & 58 & $23.02 \%$ & 16 & $6.35 \%$ & 252 & $9.11 \%$ \\
\hline 2009 & 79 & $29.70 \%$ & 111 & $41.73 \%$ & 60 & $22.56 \%$ & 16 & $6.02 \%$ & 266 & $9.62 \%$ \\
\hline 2010 & 74 & $27.82 \%$ & 116 & $43.61 \%$ & 60 & $22.56 \%$ & 16 & $6.02 \%$ & 266 & $9.62 \%$ \\
\hline 2011 & 78 & $27.86 \%$ & 119 & $42.50 \%$ & 66 & $23.57 \%$ & 17 & $6.07 \%$ & 280 & $10.13 \%$ \\
\hline 2012 & 71 & $25.63 \%$ & 122 & $44.04 \%$ & 67 & $24.19 \%$ & 17 & $6.14 \%$ & 277 & $10.02 \%$ \\
\hline 2013 & 65 & $23.72 \%$ & 125 & $45.62 \%$ & 68 & $24.82 \%$ & 16 & $5.84 \%$ & 274 & $9.91 \%$ \\
\hline 2014 & 61 & $22.51 \%$ & 124 & $45.76 \%$ & 70 & $25.83 \%$ & 16 & $5.90 \%$ & 271 & $9.80 \%$ \\
\hline 2015 & 52 & $20.39 \%$ & 119 & $46.67 \%$ & 68 & $26.67 \%$ & 16 & $6.27 \%$ & 255 & $9.22 \%$ \\
\hline Total & 717 & $25.93 \%$ & 1200 & $43.40 \%$ & 672 & $24.30 \%$ & 176 & $6.37 \%$ & 2765 & $100.00 \%$ \\
\hline
\end{tabular}

Source: Own elaboration

Table 10

Test of independence

\begin{tabular}{|l|c|c|c|}
\hline Test & Statistic & Degrees of freedom & P-Value \\
\hline Chi-Square & 14.477 & 30 & 0.9924 \\
\hline
\end{tabular}

Source: Own elaboration

Next, the share of companies that disclose intangible assets to companies that publish their financial statements is analyzed. To do so, the data contained in Table 9 are compared with the number of companies shown in Table 6 . The final share for the groups classifying companies according to their size is shown in 
Table 11. Based on that, it can be concluded that, on average, $32.61 \%$ micro companies, $63.43 \%$ small companies, $89.11 \%$ medium-sized companies and $96.70 \%$ large companies that publish their financial statements disclose intangible assets. As the data show, the share is higher for larger companies, so it can be concluded that larger companies disclose intangible assets more often than the smaller ones. Analyzing the development over time, it can be concluded that the share by small and large companies does not change over time. On the other hand, the share by micro companies has fallen over time, and the share by mediumsized companies has increased during the research period.

Table 11

The structure of companies disclosing intangible assets in individual years

\begin{tabular}{|l|l|c|c|c|}
\hline \multirow{2}{*}{ Year } & \multicolumn{3}{|c|}{ Share of companies disclosing intangible assets in \% } \\
\cline { 2 - 5 } & Micro & Small & Medium-sized & Large \\
\hline 2005 & 0.4065 & 0.6466 & 0.8182 & 0.9375 \\
\hline 2006 & 0.4178 & 0.6090 & 0.8966 & 0.9375 \\
\hline 2007 & 0.3608 & 0.6178 & 0.9063 & 1.0000 \\
\hline 2008 & 0.3730 & 0.6294 & 0.8657 & 1.0000 \\
\hline 2009 & 0.3480 & 0.6250 & 0.8955 & 1,0000 \\
\hline 2010 & 0.3109 & 0.6203 & 0.8219 & 0.9412 \\
\hline 2011 & 0.3210 & 0.6103 & 0.8904 & 1.0000 \\
\hline 2012 & 0.3021 & 0.6256 & 0.8933 & 1.0000 \\
\hline 2013 & 0.2766 & 0.6579 & 0.9189 & 0.8889 \\
\hline 2014 & 0.2837 & 0.6631 & 0.9333 & 0.9412 \\
\hline 2015 & 0.2680 & 0.6685 & 0.9444 & 1.0000 \\
\hline Total & 0.3261 & 0.6343 & 0.8911 & 0.9670 \\
\hline
\end{tabular}

Source: Own elaboration

Furthermore, the relationship between the ratio which measures the proportion of intangible assets to tangible ones and net total assets is studied. Table 12 shows the results of the correlation analysis for each of the four groups classifying companies according to their size.

Table 12

Correlation analysis

\begin{tabular}{|l|c|c|c|}
\hline \multirow{2}{*}{ Category } & \multicolumn{3}{|c|}{ Spearman rank correlation } \\
\cline { 2 - 4 } & Correlation & Sample size & P-Value \\
\hline Micro & 0.2296 & 1.974 & 0.0000 \\
\hline Small & 0.1801 & 1.787 & 0.0000 \\
\hline Meidum-sized & -0.0796 & 745 & 0.0298 \\
\hline Large & 0.0862 & 181 & 0.2472 \\
\hline
\end{tabular}

Source: Own elaboration

As shown in Table 12 by micro, small and medium sized companies intangible assets are correlated to net total assets. The relationship is positive by micro and small companies, whereas by the medium-sized ones there is a slight negative correlation. As the P-Value in there three cases is lower than 0.05 , the H4 hypothesis can be rejected at the $95.0 \%$ confidence level. This means that there is a statistically significant relationship between the he proportion of intangible assets to tangible ones and net total assets. On the other hand, by large companies the P-Value is higher than 0.05 and, therefore, the H4 hypothesis cannot be rejected at the $95.0 \%$ confidence level. So then by large companies there is no statistically significant relationship between the he proportion of intangible assets to tangible ones and net total assets. 


\section{CONCLUSION}

The aim of this paper was focused on relationship between the size of a company and the disclosure of intangible assets by enterprises operating in the field of information and communication activities in the Czech Republic. Firstly, the issue of the publication of the financial statement by the analyzed companies was studied. Subsequently, the disclosure of intangible assets was analyzed. The share between intangible and tangible assets was particularly analyzed against the rising amount of net total assets.

When studying the publication of the financial statements, it was found that about two thirds of the companies incorporated in the research sample published their financial statements in accordance with the legislative requirements. In addition, it can be concluded that larger companies publish their financial statements for a longer period than smaller ones. Studying the structure of publishing companies in individual years confirmed that the structure of publishing companies does not change over time.

In the next step, it was shown that the structure of companies disclosing intangible assets does not change over time. When comparing the numbers of companies publishing their financial statements and companies disclosing intangible assets, it was found that larger companies disclose intangible assets more often than the smaller ones.

In the last analysis, it was confirmed that the share of intangible assets to fixed assets is higher by larger companies. In small and medium-sized companies, the share is slightly declining when the net total assets are increasing, whereas in the case in micro and large companies the share is equal to a constant number.

Results of this research add knowledge regarding the economic consequences of mandatory regulations of the Czech accounting and have an appeal to regulators and financial statement preparers. It is especially proposed to continue with the process of harmonization of the Czech accounting to European accounting regulation and the unification of the reporting rules for any accounting unit. Moreover, the Czech accounting regulation should increase the guidance and principles on presentation and disclosure in financial statements as it is required by the IFRS.

In order to obtain a broader picture describing the publication of financial statements of companies disclosing intangible assets, either the research sample will be extended to other types of legal entities operating in the field of information and communication activities, or the analysis shall be focused on some other types of activities included in another fields according to CZ NACE. Both these approaches will include more companies in the research sample.

\section{ACKNOWLEDGEMENT}

This paper was created in accordance with the institutional support for the conceptual development of the Technical University of Liberec, Faculty of Economics - Project: Excellent Research Teams - New Approaches for the Reporting of Intellectual Assets in the Czech Environment (Excelentní výzkumné týmy - NOVÉ PŘíSTUPY K VYKAZOVÁNÍ NEHMOTNÝCH AKTIV V PROSTŘEDÍ ČR).

\section{REFERENCES}

Act No. 563/1991 Coll., on Accounting. Ministry of Finance of the Czech Republic.

Brabec, Z. \& Malíková O. (2016). The Role of Intangible Assets Recognised by Czech Companies Listed on the Prague Stock Exchange. Proceedings of the 3rd International Multidisciplinary Scientific Conferences on Social Sciences and Arts SGEM 2016, Volume III., 639-646.doi: http://10.5593/sgemsocial2016B23

Cheung, E. \& Lau, J. (2016). Readability of Notes to the Financial Statements and the Adoption of IFRS. Australian Accounting Review, 26(2), 162-176. doi: 10.1111/auar.12087

Clausen, S. \& Hirth, S. (2016). Measuring the value of intangibles. Journal of Corporate Finance, 40(2016), 110-127. doi: http://dx.doi.org/10.1016/j.jcorpfin.2016.07.012 
Corrado, C., Hulten, C., \& Sichel, D. (2009). Intangible capital and US economic growth. Review of income and wealth, 55(3), 661-685.

Decree No. 500/2002 Coll, on Accounting Act, for entrepreneurs. Ministry of Finance of the Czech Republic.

Gu, F. \& Wang, W. (2005). Intangible Assets, Information Complexity, and Analysts' Earnings Forecasts. Journal of Business Finance \& Accounting, 32(9\&10), 1973-1702. doi: 10.1111/j.0306-686X.2005.00644.x

Hall B. H. \& Kim D. (2000). Valuing Intangible Assets: The Stock Market V alue of R\& D Revised, Working Paper, Berkeley, CA and Cambridge, MA: University of California at Berkeley and Harvard University.

Hasprová, O. et al. (2016). Výkonnost podniku v závislosti na úcetnich, finaníních a danooých faktorech. Liberec: Technická univerzita v Liberci. ISBN 978-80-7494-309-6.

Hasprova, O. \& Brabec, Z. (2014). The Importance of Intangible Assets in a Company Engaged in the Development of Advanced Technologies. Proceedings of the SGEM International Multidisciplinary Scientific Conferences on Social Sciences and Arts SGEM 2014, Volume II., 769-776. doi: http://10.5593/sgemsocial2014B22

Hasprová, O., Brabec, Z., \& Rozkovec, J. (2018). Intangible assets disclosed by public universities in Czech Republic. Journalof International Studies, 11(1), 67-79. doi:10.14254/2071-8330.2018/11-1/5

Helmers, C., Schulte C., \&Strauss, H. (2009). Business R\&D expenditure and capital in Europe, EIB paper, 14(1), 3661.

IASB. (2018). IFRS® Standards — Required 1 January 2018 (Blue Book.).London: International Accounting Standards Board.

Jac, I., Sedlar, J., Zaytsev, A. \& Zaytsev, A. (2015).Specificity of Forming the Incremental Value of a High-Technology Enterprise on the Basis of Implementing Innovative Managerial Techniques. Proceedings of the 12th International Conference Liberec Economic Forum, 272-285.

Jones, S. (2011). Does the Capitalization of Intangible Assets Increase the Predictability of Corporate Failure? Accounting Horizons, 25(1), 41-70. https://doi.org/10.2308/acch.2011.25.1.41

Krizova, Z. (2016). Reporting of Intangibles in Different Reporting Systems. Proceedings of the 3rd International Multidisciplinary Scientific Conferences on Social Sciences and Arts SGEM 2016, Volume III., 321-328. doi: http://10.5593/sgemsocial2016B23

Krizova, Z. (2017). Reporting of Goodwill in Mergers \& Acquisitions. Proceedings of the $14^{\text {th }}$ International Scientific Conference European Financial Systems 2017, 426-431. WOS:000418110700052.

Krstic, J. \& Dordevic, M. (2010). Financial Reporting on Intangible Assets: Scope and Limitations. Economics and Organization, 7(3), 335-348.

Lev, B. (2003). Remarks on the Measurement, Valuation, and Reporting of Intangible Assets. Economic Policy Review, 2003(Sep), 17-22.

Lev, B. (2004). Sharpening the Intangible Edges. Harvard Business Review, 82(6), 109-116.

Michalczuk, G. \& Widelska, U. (2016). Disclosing Intangible Assets in Company Annual Reports: Evidence from Poland. 21st International Scientific Conference on Smart and Efficient Economy - Preparation for the Future Innovative Economy, 455-462. WOS:000408885200057.

Nakamura, L. I. (2008). Intangible Assets and National Income Accounting. Working Paper No. 08-23. Federal Reserve Bank of Philadelphia.

Nakamura, L. I. (2010). Intangible Assets and National Income Accounting. Review of Income and Wealth, 56(1), 135-155.

Neibel, T. \& O’Mahony, M. \& Saam, M. (2017). The Contribution of Intangible Assets to Sectoral Productivity Growth in the EU. Review of Income and Wealth, 63(SI), S49-S67. doi: 10.1111/roiw.12248

Nobes, Ch. \& Parker, R. B. (2016). Comparative International Accounting. 13 $3^{\text {th }}$ ed. UK: Financial Times Prentice Hall.

Sabolovic, M. (2011). Kvantitativní analýza trendu vývoje hodnoty nehmotného majetku v České republice. Ekonomický časopis, 59(10), 1018-1032.

Salojärvi, S., Furu, P., \&Sveiby, K. E. (2005). Knowledge management and growth in Finnish SMEs. Journal of knowledge management, 9(2), 103-122.

Sedlacek, J. (2010). Analysis of the Development of Intangible Assets in the Czech Enterprises and their Impact on Financial Position and Performance. Ekonomický časopis, 58(4), 375-391. 
Sedlacek, J., Valouch, P., Hyblova, E. \& Krizova, Z. (2014). Changes in Property and Ownership Structure of Companies as a Consequence of Mergers in the Czech Republic. Inzinerine Ekonomika - Engineering Economics, 25(2), 152-159.doi: http://dx.doi.org/10.5755/j01.ee.25.2.4030

Schiemann, F. \& Richter, F. \& Gunther, T. (2015). The relationship between recognized assets and voluntary intellectual capital disclosure. Journal of applied accounting research, 16(2), 240-264. doi: 10.1108/JAAR-11-20120076

Stolowy, H., \& Jeny-Cazavan, A. (2001). International accounting disharmony: the case of intangibles. Accounting, Auditing and Accountability Journal, 14(4), 477-496.

Sveiby, K.E. (1989). The Invisible Balance Sheet. Stockholm: Affarfgarblen.

Svoboda, P., Bohusova, H. \& Semeradova, L. (2017). Intangible assets in Pharmaceutical Companies in the Czech Republic. Proceedings of the 14th International Scientific Conference European Financial Systems 2017, Part 2., 391-399.

Wyatt A. \& Abernathy M. A. (2003). Framework for Measurement and Reporting on Intangible Assets. Working Paper No. 12/03. Melbourne: Intellectual Property Research Institute of Australia. 